\title{
KEMANDIRIAN KONSUMEN DI ERA GLOBALISASI \\ DAN PERDAGANGAN BEBAS \\ (Kajian Mengenai Undang-undang Perlindungan Konsumen No. 8 \\ Tahun 1999 Terhadap Perlindungan Hak-hak Konsumen)
}

\author{
Oleh : \\ Emei Dwinanarhati Setiamandani*
}

\begin{abstract}
The Application of a free trade in the globalization are has resulted in a tight competition in the economic sector. In order to protect consumers from detrimental actions done business actors in the transaction of products and services, the government have made a regulation on the consumer protection. This present study was intended to understand the protection guarantee the government give on the basis of the 1999 consumer protection laws in the free trade in this globalization era.

In this present study, a normative judicial approach was employed. In this approach, a legal examination was made based on the study on the legislation regulation and literatures in order to analyse the emerging problems.

The result of the study showed tha the application of the 1999 consumer protection laws no. 8 proved that the protection to the consumers was given by all parties, namely among others, the government, the people, and consumer protection organizations. It hopefully may give the consumers in the globalization era an equal position with the business actors.
\end{abstract}

Kata kunci: Globalisasi, perlindungan, konsumen, dan pemerintah

\section{PENDAHULUAN}

Globalisasi dan perdagangan bebas yang didukung dengan kemajuan teknologi komunikasi telah memperluas ruang gerak arus transaksi barang dan/atau jasa. Kondisi tersebut, di satu sisi mempunyai manfaat bagi konsumen karena segala kebutuhan konsumen dapat terpenuhi, serta semakin terbuka lebar kebebasan untuk memilih aneka jenis kualitas barang dan jasa sesuai keinginan dan kemampuan konsumen.

Namun disisi lain, kondisi dan fenomena demikian dapat mengakibatkan kedudukan konsumen berada pada posisi yang lemah. Khususnya di Indonesia, banyak terjadi penyimpangan yang menjadikan konsumen

\footnotetext{
- Dosen pada FakuItas Hukum Universitas Muhammadiyah Malang
}

sebagai objek aktivitas bisnis untuk meraup keuntungan yang sebesar-besarnya oleh pelaku usaha melalui kiat promosi, cara penjualan, serta penerapan perjanjian standar yang merugikan konsumen. ${ }^{1}$

Karena posisi konsumen yang sangat lemah tersebut, Pemerintah membuat regulasi mengenai perlindungan konsumen yang termaktub dalam Undang-undang Perlindungan Konsumen (UUPK) No. 8 Tahun 1999. Lahirnya UU Perlindungan Konsumen tersebut menjadi landasan hukum bagi pelaksanaan upaya pemberdayaan konsumen dan diharapkan dapat mengantar konsumen Indonesia menjadi konsumen yang mandiri,

"Rahayu, Hartini. 2005. Hukum Komersial. Malang:UMM Press. Halaman 199

Kemandirian Konsumen. . . | 25 
meningkat harkat dan martabatnya, mengetahui hak dan kewajibannya yang pada saatnya dapat mendorong iklim usaha yang sehat.

Sementara kepada para pelaku usaha diharapkan dalam melakukan kegiatan usaha menempatkan konsumen tidak semata-mata menjadi target pasar namun juga harus mempertimbangkan konsumen menjadi jaminan pasar dalam rangka jangka panjang.

Bisa kita amati, sering terjadi pelanggaran hak-hak konsumen. Misalnya pelanggaran pada penjualan produk dan penyelenggaraan jasa, seperti misalnya pada produk mengenai obat nyamuk HIT yang harus ditarik dari peredaran lantaran kandungan dua zat aktifnya yakni propoksur dan diklorvos yang seharusnya dua zat tersebut dipakai pada pertanian dan perkebunan dan pekerjanya diharuskan memakai pelindung. Selain itu pada minuman juga pernah terjadi penarikan barang dari edaran seperti misalnya kasus minuman mizone, pengoplosan daging sapi dengan daging babi hutan, penggunaan formalin pada produk makanan sehari-hari.

Dengan adanya kejadian tersebut, konsumen jelas dirugikan. Lalu, dapatkah konsumen membuktikan dirinya dirugikan oleh akibat yang ditimbulkan dengan pemakaian merek barang yang palsu tersebut. Pembuktian konsumen terkontaminasi, agaknya sulit, karena harus melalui pembuktian laboratorium. Karenanya, posisi konsumen lemah jika dihadapkan dengan produsen atau penjual. Sehingga, perlu ada tindakan tegas pemerintah dan usaha keras dari Yayasan Lembaga Konsumen Indonesia (YLKI) dalam hal lebih serius mengontrol produk barang yang beredar serta mempersoalkan produsen atau penjual yang 'bermasalah' melalui jalur hukum, agar praktik yang merugikan tersebut tidak tumbuh subur di pasaran.
Pelanggaran hak konsumen tersebut diatas terjadi karena disebabkan beberapa hal, diantaranya ; (1) kurangnya kesadaran masyarakat akan haknya sebagai konsumen, (2) masih lemahnya perhatian konsumen terhadap penggunaan produk dengan tidak mencoba untuk mengetahui informasi, prosedur pemakaian dan pemanfaatan suatu produk demi keamanan dalam berkonsumsi, (3) kurangnya SDM masyarakat sebagai pelaku konsumen, (4) adanya keinginan dari pelaku usaha untuk mendapat keuntungan yang sebesar-besarnya tanpa memperdulikan kesehatan konsumen, (5) kurangnya perhatian dari Pemerintah dalam hal pengawasan peredaran produk di masyarakat dan pelayanan jasa oleh pelaku usaha.

Pemerintah juga harus tetap melakukan pembinaan dan pengawasan terhadap konsumen dan pelaku usaha agar tercipta iklim usaha yang sehat sehingga dapat meningkatkan pembangunan ekkonomi secara riil. Selain itu juga bagi pelaku usaha hendaknya jangan hanya menjadikan konsumen sebagai obyek untuk meraih keuntungan, akan tetapi menjadikan partner dalam transaksi perekonomian. Dengan demikian jika kondisi tersebut dapat diwujudkan, maka akan dapat meminimalisir pelanggaran terhadap hak-hak konsumen.

Mengingat pentingnya konsumen untuk dapat memperjuangkan hak-haknya agar tidak selalu dirugikan oleh produsen sehingga konsumen mendapatkan perlindungan hukum, maka dalam penelitian ini lebih memfokuskan pada permasalahan yaitu, "Bagaimana Undang-undang Perlindungan Konsumen (UUPK) No. 8 Tahun 1999 dalam memberikan jaminan perlindungan terhadap konsumen di era globalisasi perdagangan Bebas?"

Adapun tujuan penelitian ini adalah untuk mengetahui dan menganalisa mengenai jaminan perlindungan yang diberikan kepada 
konsumen oleh UUPK No. 8 Tahun $1999 \mathrm{di}$ era globalisasi perdagangan bebas.

\section{METODE PENELITIAN}

Penelitian ini menggunakan metode pendekatan yuridis normatif, yaitu penelitian hukum yang bertitik tolak dari studi peraturan perundang-undangan dan bahan pustaka untuk menganalisa permasalahan yang timbul. ${ }^{2}$

Sedang untuk analisis data, penelitian ini menggunakan deskriptif normatif, yaitu pengolahan data yang didasarkan pada hasil kajian peraturan perundang-undangan yang kemudian dipadukan dengan yang didapat dari hasil studi kepustakaan. ${ }^{3}$

\section{HASIL DAN PEMBAHASAN}

\section{A. Perlindungan Konsumen}

Dilihat dari sejarahnya, gerakan perlindungan konsumen di Indonesia baru dipopulerkan sekitar 20 tahun yang lalu, yakni dengan berdirinya lembaga swadaya masyarakat (non governmental organization) yang bernama Yayasan Lembaga Konsumen Indonesia (YLKI). Yayasan ini semula tidak ingin berkonfrontasi dengan produsen, apalagi dengan pemerintah. YLKI memiliki cabang diberbagai provinsi dan mempunyai pengaruh yang cukup besar karena didukung oleh media massa. ${ }^{4}$ YLKI diharapkan mampu memberi manfaat bagi semua kelompok/lapisan masyarakat tanpa mengenal batas-batas kesukuan, agama, etnis, dan status sosial ekonomi.

Perlindungan konsumen adalah upaya yang terorganisir yang didalamnya terdapat unsur-unsur pemerintah, konsumen, dan pelaku

${ }^{2}$ Bambang Waluyo, 2002. Penelitian Hukuim Dalam Praktek. Jakarta : Sinar Grafika. Halaman 16

${ }^{9}$ Ibid. hal. 17

4 Ibid halaman 49 usaha yang jujur dan bertanggung jawab untuk meningkatkan hak-hak konsumen. ${ }^{5}$ Sedangkan dalam pasal 1 ayat 1 UUPK No. 8 Tahun 1999 , dikatakan bahwa perlindungan konsumen adalah "segala upaya yang menjamin adanya kepastian hukum untuk memberikan perlindungan hukum kepada konsumen". ${ }^{6}$

Rumusan pengertian perlindungan konsumen yang termuat dalam pasal 1 ayat 1 UUPK No. 8 Tahun 1999 telah memadai. Kalimat yang menyatakan "segala upaya yang menjamin adanya kepastian hukum", diharapkan sebagai benteng untuk meniadakan tindakan sewenang-wenang yang merugikan pelaku usha hanya demi untuk kepentingan perlindungan konsumen. dalam UUPK kepentingan pelaku usaha juga menjadi perhatian, teristimewa karena keberadaan perekonomian nasional banyak ditentukan oleh pelaku usaha. ${ }^{7}$

\section{B. Kemandirian Konsumen}

Kemandirian, menurut Sutari Imam Barnadib (1982), meliputi “perilaku mampu berinisiatif, mampu mengatasi hambatan/ masalah, mempunyai rasa percaya diri dan dapat melakukan sesuatu sendiri tanpa bantuan orang lain". Pendapat tersebut juga diperkuat oleh Kartini dan Dali (1987) yang mengatakan bahwa kemandirian adalah "hasrat untuk mengerjakan segala sesuatu bagi diri sendiri”. Secara singkat dapat disimpulkan bahwa kemandirian mengandung pengertian:

"Ika Mheutiah. 2004."Rahasia Dagang dan Perlindungan Konsumen ${ }^{n}$.Google volume 1 tanggal akses 9-04-2007.

" Lihat pasal 1 angka 1 UU No 8 Tahun 1999 tentang Perlindungan Konsumen Pasal 1 (angka1)" Perlindungan kmonsumen adalah segala upaya yang menjamin adanya kepastian hukum untuk memberikan perlindungan kepada konsumen."

${ }^{7}$ Miru, Ahmadi, dkk. 2004. Hukum Perlindungan Konsumen. Jakarta: PT. Raja Grafindo Persada . Halaman: 1

Kemandirian Konsumen.. . I 
1. Suatu keadaan dimana seseorang yang memiliki hasrat bersaing untuk maju demi kebaikan dirinya,

2. Mampu mengambil keputusan dan inisiatif untuk mengatasi masalah yang dihadapi,

3. Memiliki kepercayaan diri dalam mengerjakan tugas-tugasnya,

4. Bertanggungjawab tetrhadap apa yang dilakukannya. $^{8}$

Kemandirian merupakan suatu sikap individu yang diperoleh secara kumulatif selama perkembangan, dimana individu akan terus belajar untuk bersikap mandiri dalam menghadapi berbagai situasi di lingkungan, sehingga individu pada akhirnya akan mampu berpikir dan bertindak sendiri. Dengan kemandiriannya seseorang dapat memilih jalan hidupnya untuk dapat berkembang dengan lebih mantap. ${ }^{9}$

Sehubungan dengan tujuan dari perlindungan konsumen sendiri, yang mengupayakan terciptanya kemandirian pada konsumen. Kemandirian konsumen yang dimaksud adalah kemandirian didalam memahami kebutuhannya, memahami kemampuannya, memilih produk sesuai dengan kebutuhan dan kemampuan, menyadari akibat dari keputusan/pilihannya, serta kemampuan, dan kemandirian konsumen untuk melindungi dirinya. $^{10}$

\section{Globalisasi dan Perdagangan Bebas}

\section{Globalisasi}

Kata "globalisasi" diambil dari kata global, yang maknanya ialah universal. Globalisasi belum memiliki definisi yang mapan, kecuali sekadar definisi kerja (work-

\footnotetext{
${ }^{8}$ Mu'tadin, Zainun. 2002. Kemandirian Sebagai Kebutuhan Psikologis Remaja. Google volume 1. Tanggal Akses 20-07-2007

${ }^{9}$ Wira Sutedja, 2007. Panduan Layanan Konsumen. Jakarta : PT. Grasindo

${ }^{10} \mathrm{Ibid}$, halaman 19.
}

ing definition), sehingga tergantung dari sisi mana orang melihatnya. Ada yang memandangnya sebagai suatu proses sosial, atau proses sejarah, atau proses alamiah yang akan membawa seluruh bangsa dan negara di dunia makin terikat satu sama lain, mewujudkan satu tatanan kehidupan baru atau kesatuan koeksistensi dengan menyingkirkan batas-batas geografis, ekonomi dan budaya masyarakat. ${ }^{11}$

Mitos yang hidup selama ini tentang globalisasi adalah bahwa proses globalisasi akan membuat dunia seragam. Proses globalisasi akan menghapus identitas dan jati diri. Kebudayaan lokal atau etnis akan ditelan oleh kekuatan budaya besar atau kekuatan budaya global.

Anggapan atau jalan pikiran di atas tersebut tidak sepenuhnya benar. Kemajuan teknologi komunikasi memang telah membuat batas-batas dan jarak menjadi hilang dan tak berguna. John Naisbitt (1988), dalam bukunya yang berjudul Global Paradox ini memperlihatkan hal yang justru bersifat paradoks dari fenomena globalisasi. Naisbitt (1988) mengemukakan pokok-pokok pikiran lain yang paradoks, yaitu semakin kita menjadi universal, tindakan kita semakin kesukuan, dan berpikir lokal, bertindak global. Hal ini dimaksudkan kita harus mengkonsentrasikan kepada hal-hal yang bersifat etnis, yang hanya dimiliki oleh kelompok atau masyarakat itu sendiri sebagai modal pengembangan ke dunia Internasional. ${ }^{12}$

Di sisi lain, ada yang melihat globalisasi sebagai sebuah proyek yang diusung oleh negara-negara adikuasa, sehingga bisa saja orang memiliki pandangan negatif atau curiga terhadapnya. Dari sudut pandang ini, globalisasi tidak lain adalah kapitalisme dalam

"Wilkipedia Indonesia. Globalisasi.Google volume 1. tanggal akses 20-07-2007

${ }^{12}$ Ibid

28 Kemandirian Konsumen... 
bentuknya yang paling mutakhir. Negaranegara yang kuat dan kaya praktis akan mengendalikan ekonomi dunia dan negaranegara kecil makin tidak berdaya karena tidak mampu bersaing. Sebab, globalisasi cenderung berpengaruh besar terhadap perekonomian dunia, bahkan berpengaruh terhadap bidangbidang lain seperti budaya dan agama. ${ }^{13}$

Kennedy dan Cohen menyimpulkan bahwa transformasi ini telah membawa kita pada globalisme, sebuah kesadaran dan pemahaman baru bahwa dunia adalah satu. Giddens menegaskan bahwa kebanyakan dari kita sadar bahwa sebenarnya diri kita turut ambil bagian dalam sebuah dunia yang harus berubah tanpa terkendali yang ditandai dengan selera dan rasa ketertarikan akan hal sama, perubahan dan ketidakpastian, serta kenyataan yang mungkin terjadi. Sejalan dengan itu, $\underline{\mathrm{Pe}}-$ ter Drucker menyebutkan globalisasi sebagai zaman transformasi sosial. Setiap beberapa ratus tahun dalam sejarah manusia, transformasi hebat terjadi. Dalam beberapa dekade saja, masyarakat telah berubah kembali baik dalam pandangan mengenai dunia, nilainilai dasar, struktur politik dan sosial, maupun seni. Lima puluh tahun kemudian muncullah sebuah dunia baru..$^{14}$

\section{Perdagangan Bebas}

Perdagangan bebas adalah sebuah konsep ekonomi yang mengacu kepada penjualan produk antar negara tanpa pajak ekspor-impor atau hambatan perdagangan lainnya. Perdagangan bebas dapat juga didefinisikan sebagai tidak adanya hambatan buatan (hambatan yang diterapkan pemerintah) dalam perdagangan antar individual-individual

${ }^{13}$ Husni Syawali, Neni Sri Imaniyati, 2000. Hukum Perlindungan Konsumen. Bandung: Mandar Maju. Halaman. 15

14 Wilkipedia Indonesia. Globalisasi.Google volume 1. tanggal akses 20-07-2007 dan perusahaan-perusahaan yang berada di negara yang berbeda. ${ }^{15}$

Perdagangan internasional sering dibatasi oleh berbagai pajak negara, biaya tambahan yang diterapkan pada barang ekspor impor, dan juga regulasi non tarif pada barang impor. Secara teori, semuha hambatanhambatan inilah yang ditolak oleh perdagangan bebas. Namun dalam kenyataannya, perjanjianperjanjian perdagangan yang didukung oleh penganut perdagangan bebas ini justru sebenarnya menciptakan hambatan baru kepada terciptanya pasar bebas. Perjanjianperjanjian tersebut sering dikritik karena melindungi kepentingan perusahaanperusahaan besar.

Banyak ekonom yang berpendapat bahwa perdagangan bebas meningkatkan standar hidup melalui teori keuntungan komparatif dan ekonomi skala besar. Sebagian lain berpendapat bahwa perdagangan bebas memungkinkan negara maju untuk mengeksploitasi negara berkembang dan merusak industri lokal, dan juga membatasi standar kerja dan standar sosial. Sebaliknya pula, perdagangan bebas juga dianggap merugikan negara maju karena ia menyebabkan pekerjaan dari negara maju berpindah ke negara lain dan juga menimbulkan perlombaan serendah mungkin yang menyebabkan standar hidup dan keamanan yang lebih rendah. Perdagangan bebas dianggap mendorong negara-negara untuk bergantung satu sama lain, yang berarti memperkecil kemungkinan perang. ${ }^{16}$

\section{PEMBAHASAN}

Berbicara mengenai perlindungan hukum terhadap konsumen di Indonesia

13 Wikipedia Indonesia. Perdagangan Bebas. Google volume 1. Tanggal Akses 17-07-2007

${ }^{16} \mathrm{Ibid}$

Kemandirian Konsumen. . . 29 
tentunya tidak terlepas dari instrument yuridis yaitu UUPK No. 8 Tahun 1999. Jika di Negara maju seperti contohnya Amerika Serikat, alasan utama yang dipandang sebagai penyebab lahirnya hukum perlindungan konsumen adalah karena berkembangnya industri secara cepat dan menunjukkan kompleksitas yang tinggi sehingga menimbulkan banyak korban karena memakai atau menkonsumsi produk-produk industri. Sedangkan di Indonesia sebagai Negara berkembang yang masyarakatnya semakin dituntut untuk memenuhi kebutuhan barang dan jasa akan lebih banyak menerima/ mendatangkan produk dari luar negeri yang belum tentu aman jika dikonsumsi oleh masyarakat Indonesia. Selain itu juga karena belum adanya sumber daya manusia yang bagus, konsumen di Indonesia belum bisa mendiri untuk memperjuangkan hak-haknya apabila dirugikan oleh produsen.

Perlindungan terhadap konsumen harus mendapat perhatian yang lebih, karena investasi asing telah menjadi bagian dari pembangunan ekonomi Indonesia, dimana ekonomi Indonesia telah terkait dengan ekonomi dunia. Persaingan perdagangan internasional dapat membawa implikasi negatif bagi perlindungan konsumen.

Namun demikian, upaya untuk memberi perlindungan hukum terhadap konsumen tidak berarti telah ada anggapan dasar bahwa semua pihak yang bergerak di bidang usaha dan perdagangan selalu terlibat dalam manipulasi yang merugikan para konsumen dan tidak pula dimasukkan untuk menjadikan masyarakat tidak konsumeristis. Akan tetapi, perlindungan terhadap konsumen didasarkan pada adanya sejumlah hak konsumen yang perlu dilindungi dari tindakan-tindakan yang merugikan yang dilakukan oleh pihak lain. Hak-hak ini merupakan hak-hak yang sifatnya mendasar dan universal sehingga perlu mendapat jaminan dari negara atas pemenuhannya, seperti yang sudah dijabarkan pada Bab II, yaitu terdapat pada pasal 4 UUPK No. 8 Tahun 1999.

Hak atas kenyamanan, keamanan, dan keselamatan mengandung pengertian bahwa konsumen berhak mendapatkan produk yang aman, nyaman, dan yang memberi keselamatan. Oleh karena itu konsumen harus dilindungi dari segala bahaya yang mengancam kesehatan, jiwa, dan harta bendanya karena memakai atau menkonsumsi produk (misalnya makanan). Selain itu, Negara juga harus menjamin keamanan dana keselamatan konsumen dalam penggunaan jasa yang diperolehnya (misalnya dalam transportasi), sehingga konsuen dapat terhindar dari kerugian fisik maupun psikis. Termasuk dalam hal ini juga adalah produsen harus memeriksa barang yang sudah daluwarsa (expired) dan tidak layak untuk dikonsumsi. Dengan demikian sangat penting sekali konsumen mendapat jaminan perlindungan yang berupa hak untuk memperoleh informasi.

Hak atas informasi ini sangat penting, karena tidak memadainya informasi yang disampaikan kepada konsumen dapat juga merupakan salah satu bentuk cacat produk atau cacat pelayanan jasa. Dalam hal berproduksi produsen diharuskan bertindak jujur, benar, dan jelas sehingga tidak mengelabui atau membodohi konsumen. Karena itu pemafaatan media informasi oleh produsen, baik dengan iklan, billboard, dan media lainnya hendaknya dilandasi kejujuran dan niat baik.

Apabila setelah menkonsumsi, konsumen merasa dirugikan atau dikecewakan karena ternyata produk yang dikonsumsinya tidak sesuai dengan informasi yang diterimanya, produsen seharusnya mendengar keluhan tersebut dan memberikan penyelesaian yang baik. Termasuk dalam hal ini adalah hak konsumen untuk mendapatkan penggantian atas kerugian yang dideritanya setelah 
menkonsumsi produk atau jasa jika tidak sesuai dengan perjanjian. Misalnya jika pada produk terdapat label informasi mengenai manfaat produk, efek samping penggunaan produk, kadaluwarsa, serta identitas produsen dari produk tersebut. Sedangkan pada penggunaan jasa, konsumen mendapat pelayanan (sevice) jasa yang tidak sebagaimana mestinya sesuai dengan perjanjian awal. Dalam hal pemenuhan hak-hak konsumen tersebut, tentunya konsumen juga dihadapkan pada kewajiban yang harus dipenuhinya juga, seperti misalnya membayar sesuai dengan dengan nilai tukar yang disepakati sehingga ada timbal balik antara konsumen - produsen untuk saling memenuhi hak dan kewajiban masing-masing pihak.

Mengingat bahwa produsen berada dalam kedudukan yang lebih kuat, baik secara ekonomis maupun dari segi kekuasaan (bargaining power) dibandingkan dengan konsumen, maka konsumen perlu mendapat advokasi, perlindungan, serta upaya penyelesaian sengketa.

Dengan demikian, sesuai pasal 1 ayat UUPK No. 8 Tahun 1999 jika perlindungan konsumen diartikan sebagai segala upaya yang menjamin adanya kepastian pemenuhan hakhak konsumen sebagai wujud perlindungan kepada konsumen, maka instrument hukum tersebut dapat dijadikan sebagai payung bagi perundang-undangan lain yang bertujuan untuk melindungi konsumen, baik yang sudah ada maupun yang akan dibuat nanti.

Penerapan dari ketentuan UUPK terhadap perlindungan konsumen diselenggarakan oleh Pemerintah, masyarakat, dan lembaga-lembaga perlindungan konsumen swadaya masyarakat. Sesungguhnya disinilah peranan dari masyarakat dapat secara maksimal dibangkitkan, karena UUPK No. 8 Tahun 1999 memerintahkan agar pemerintah mengakui lembaga perlindungan konsumen swadaya masyarakat yang memenuhi syarat untuk berperan aktif dalam mewujudkan perlindungan konsumen, sesuai dengan pasal 44 UUPK No. 8 Tahun 1999. Peranan lembaga swadaya masyarakat dalam bidang konsumen masih bisa signifikan di daerah perkotaan, tetapi upaya lembaga swadaya masyarakat di daerah pedesaan yang masih kurang aktif.

Sedangkan lembaga perlindungan konsumen yang di bawah naungan pemerintah adalah Badan Perlindungan Konsumen Nasional (BPKN) yang berkedudukan di Ibu Kota Negara Republik Indonesia, seperti yang telah diamanatkan oleh pasal 31 UUPK No. 8 Tahun 1999, bahwa dalam rangka mengembangkan upaya perlindungan konsumen dibentuk Badan Perlindungan Konsumen.

Berangkat dari ketentuan pasal tersebut, dapat diketahui bahwa BPKN diadakan untuk mengembangkan upaya perlindungan konsumen di Indonesia sebagai lembaga yang memberikan perlindungan konsumen yang sudah diatur dalam pasal yang lain, khususnya tentang pengaturan hak dan kewajiban konsumen dan pelaku usaha, tentang pertanggunngjawaban pelaku usaha mengenai pemberian ganti rugi, dan pengaturan penyelesaian sengketa terhadap konsumen. adanya BPKN diharapkan akan lebih melindungi konsumen dari kepentingan pelaku usaha, seperti misalnya pelaku usaha yang memasarkan produk tidak layak dikonsumsi, tidak memuat komposisi dalam label yang dikeluarkan, tidak memenuhi standar mutu, dan sebainya. Sekarang dengan adanya UUPK, produk barang/jasa telah dilarang untuk ditawarkan, dipromosikan, diiklankan, dan/atau diperdagangkan.

Saat ini pemerintah harus lebih serius menangani perlindungan konsumen, karena menjelang globalisasi perdagangan bebas, 
konsumen dituntut untuk bisa mandiri. Artinya, konsumen harus mengetahui hak-haknya dan mampu memperjuangkan hak-haknya sehingga tidak bersikap pasif apabila haknya dilanggar. Konsumen juga harus mampu mengahadapi terjadinya Globalisasi perekonomian. Dimana akan terjadi suatu proses kegiatan ekonomi dan perdagangan, dimana negara-negara di seluruh dunia menjadi satu kekuatan pasar yang semakin terintegrasi dengan tanpa rintangan batas teritorial negara. Kemandirian konsumen diupayakan dapat meningkatkan pengetahuan konsumen akan hak-haknya yang diatur dalam ketentuan perundang-undangan dan kewajibannya dalam melakukan transaksi pembelian barang dan /atau jasa serta tidak mudah tertipu dan selalu mengikuti upaya penyelesaian hukum sengketa perlindungan konsumen secara patut. Hak dari konsumen merupakan kewajiban dari pelaku usaha dan kewajiban konsumen merupakan hak dari pelaku usaha sehingga antara pelaku usaha dan konsumen mengenai hak dan kewajiban diharapkan saling mendukung dan tidak melanggar.

Kemandirian konsumen dapat mencegah terjadinya perilaku curang para pelaku usaha, serta tidak tertibnya pelaksanaan arus perdagangan suatu barang maupun jasa.

Pada dasarnya terdapat beberapa kriteria konsumen yang mandiri, antara lain:

a. Sadar akan harkat dan martabat konsumen, mampu untuk melindungi diri sendiri dan keluarganya;

b. Mampu menentukan pilihan barang dan jasa sesuai kepentingan, kebutuhan, kemampuan, dan keadaan yang menjamin keamanan, keselamatan, kesehatan konsumen sendiri;

c. Jujur dan bertanggung jawab;

d. Berani dan mampu mengemukakan pendapat serta berani memperjuangkan dan mempertahankan hak-haknya; e. Berbudaya dan sadar hukum perlindungan konsumen. ${ }^{17}$

Jika unsur-unsur kriteria kemandirian konsumen telah terbentuk, maka akan tercipta keseimbangan dalam arus perdagangan. Konsumen yang mandiri akan mengetahi hakhaknya dan akan melaksanakan hak-hak yang dimiliki. Dalam hal ini pelaku usaha akan mengurangi perilaku curang, sebab konsumen yang ada sudah lebih pintar dan tidak mudah untuk dibodohi lagi.

Konsumen dalam membeli atau memilih produk/jasa hendaknya lebih teliti terutama dalam mempertimbangkan kualitas produk, manfaat, dan efek samping penggunaan. Apabila konsumen sudah mengerti hak-haknya, maka konsumen akan mendapatkan keamanan, kenyamanan, dan keselamatan dalam menkonsumsi produk atau pada saat menggunakan jasa dari pelaku usaha. Sehingga yang terjadi adalah konsumen tidak mudah terbujuk oleh iklan atau promosi barang atau jasa yang ditawarkan, konsumen lebih teliti dalam memilih dan membeli/memakai produk/ jasa, konsumen dapat memilih barang yang bermutu dan mempunyai standar penjualan produk, dan yang lebih penting konsumen dalam membeli produk atau jasa sesuai dengan kebutuhan dan kemampuan. Dengan adanya kondisi tersebut, lembaga penyelesaian sengketa konsumen juga akan berfungsi karena konsumen tidak lagi bersikap pasif ketika pelaku usaha melakukan tindakan yang merugikan konsumen, juga tidak ada lagi keraguan dari konsumen untuk melakukan gugatan ke pengadilan ketika terjadi kasus pelanggaran konsumen.

Tetapi kondisi konsumen di Indonesia sangat memprihatinkan. Hambatan utama dalam perwujudan kemandirian konsumen

17 Direktorat Perlindungan konsumen. Google volume 1.Tanggal akses 17-07-2007 
yang sadar akan hak-haknya telah termaktub dalam UUPK No. 8 Tahun 1999 adalah permasalan sumber daya manusia yang tidak merata sehingga konsumen sangat minim kesadaran akan melakukan perlindungan terhadap hak-hynya serta permasalahan prosedur pertanggungjawaban ketika terjadi sengketa konsumen, meskipun dalam UUPK No. 8 Tahun 1999 sudah diatur mengenai penyelesaian di luar pengadilan tetapi konsumen masih enggan memperkarakan kasus-kasus yang terjadi, misalnya kerugian yang dihadapi oleh konsumen secara nominal relative kecil, konsumen beranggapan bahwa melakukan gugatan pengadilan terhadap pelaku usaha hanya membuang waktu, tenaga, dan uang.

Ketika globalisasi ekonomi terjadi, batas-batas suatu negara akan menjadi kabur dan keterkaitan antara ekonomi nasional dengan perekonomian internasional akan semakin erat. Globalisasi perekonomian di satu pihak akan membuka peluang pasar produk dari dalam negeri ke pasar internasional secara kompetitif, sebaliknya juga membuka peluang masuknya produk-produk global ke dalam pasar domestik.

Dalam globalisasi akan tercipta perdagangan bebas, yaitu sebuah konsep ekonomi yang mengacu kepada penjualan produk antar negara tanpa pajak ekspor-impor atau hambatan perdagangan lainnya. Perdagangan bebas dapat juga didefinisikan sebagai tidak adanya hambatan buatan (hambatan yang diterapkan pemerintah) dalam perdagangan antar individual-individual dan perusahaan-perusahaan yang berada di negara yang berbeda. ${ }^{18}$

Kehadiran perdagangan bebas menimbulkan prokontra dari beberapa ahli.

18 Wikipedia Indonesia. Perdagangan Bebas. Google volume 1. Tanggal Akses 17-07-2007
Banyak ekonom yang berpendapat bahwa perdagangan bebas meningkatkan standar hidup melalui teori keuntungan komparatif dan ekonomi skala besar. Sebagian lain berpendapat bahwa perdagangan bebas memungkinkan negara maju untuk mengeksploitasi negara berkembang dan merusak industri lokal, dan juga membatasi standar kerja dan standar sosial. Sebaliknya pula, perdagangan bebas juga dianggap merugikan negara maju karena ia menyebabkan pekerjaan dari negara maju berpindah ke negara lain dan juga menimbulkan perlombaan serendah mungkin yang menyebabkan standar hidup dan keamanan yang lebih rendah. Perdagangan bebas dianggap mendorong negara-negara untuk bergantung satu sama lain.

Dalam hal ini, terjadinya perdagangan bebas pada arus globalisasi jelas sangat berdampak pada para konsumen. Konsumen sebagai objek lalu lintas perekonomian dalam dunia perdagangan mengalami kesulitan dalam memberikan respon terhadap hadirnya banyak produk di pasaran. Pemberlakuan pasar bebas yang memposisikan berbagai Negara menjadi pangsa pasar bagi pelaku usaha secara bebas dapat membuat kedudukan konsumen menjadi lemah, terutama di Negara-negara berkembang yang menjadi sasaran utama bagi Negara maju untuk memasarkan produk barang maupun jasa. Hal ini dikarenakan di Negara berkembang secara dominant mempunyai jumlah penduduk yang tinggi serta tidak mempunyai tekhnogi yang dapat memenuhi kebutuhan warga negaranya, berbeda dengan Negara maju. Terutama di Indonesia banyak terjadi penyimpangan yang menjadikan konsumen sebagai objek pemasaran dari pelaku usaha untuk meraup keuntungan yang sebesar mungkin, baik dengan cara promosi, cara penjualan/ pemasaran, kuailitas barang, 
penerapan klausula baku yang merugikan konsumen, ini merupakan salah satu dampak penerapan pasar bebas bagi konsumen. ${ }^{19}$

Pada era perdagangan bebas dimana lalu lintas hubungan produsen dan konsumen menjadi semakin terbuka, campur tangan negara, kerjasama internasional sangat dibutuhkan, yaitu guna mengatur pola hubungan produsen, konsumen, dan system perlindungan konsumen. sistem perlindungan konsumen sangat membutuhkan perangkat hukum internasional disamping perangkat hukum nasional, karena mengingat konflik hukum antar negara dan pihak yang berkepentingan dalam era perdagangan bebas semakin luas dan terbuka untuk memperebutkan pasar. Selain itu, pada era perdagangan bebas dikhawatirkan terdapat persaingan yang tidak jujur, sehingga konsumen mendapatkan barang /jasa yang tidak mempunyai jaminan kualitas dengan harga yang sangat tinggi. Oleh karena itu perlu adanya kerjasama antar negara untuk membuat sistem perlindungan konsumen yang harmonis berdasarkan atas persaingan jujur.

Maka menyikapi hal tersebut sangat diperlukan pembinaan, pendidikan, dan latihan menuju pada kemandirian pada tiap konsumen..Adapun pihak-pihak yang terkait untuk melakukan pembinaan, pendidikan, dan latihan terhadap konsumen, antara lain Pemerintah, Lembaga Perlindungan Konsumen, Konsumen, dan Pelaku Usaha. Selama ini belum ada usaha, baik dari pihak pemerintah maupun lembaga-lembaga konsumen yang melakukan pembinaan, pendidikan, dan pelatihan terhadap konsuamen sehingga posisi konsumen di Indonesia bertambah terpuruk dalam kelemahannya.

\section{PENUTUP \\ Kesimpulan}

Secara umum dan mendasar hubungan antara pelaku usaha dan konsumen merupakan hubungan yang terus menerus dan berkesinambungan. Hubungan tersebut memang saling membutuhkan dan mempunyai tingkat ketergantungan yang cukup tinggi. Bertolak dari luas dan kompleksnya hubungan antara produsen dan konsumen yang akhirnya posisi pelaku usaha lebih mendominasi dari pada posisi konsumen sehingga konsumen lebih sering dirugikan, maka negara menjamin perlindungan hukum terhadap konsumen di dalam Undang-undang Perlindungan Konsumen No. 8 Tahun 1999.

Memasuki era globalisasi perdagangan bebas, dimana akses transaksi melalui sarana apapun sangat terbuka. Globalisasi yang diciptakan oleh negara-negara maju melakukan gerakan perluasan pasar dan disemua pasar yang berdasarkan persaingan selalu ada yang menang dan kalah.

Di Indonesia yang posisi konsumen masih sangat lemah, maka harus ada gerakan kemandirian konsumen sehingga konsumen siap menghadapi era perdagangan bebas. Jadi konsumen bisa lebih memahami hak-haknya dan bisa memperjuangkan apabila haknya dilanggar. Adanya UUPK No. 8 Tahun 1999 sangat menekankan adanya perlindungan terhadap konsumen oleh semua pihak, antara lain pemerintah, masyarakat, dan lembagalembaga perlindungan konsumen. sehingga diharapkan posisi konsumen di era globalisasi perdagangan bebas dapat sejajar dengan pelaku usaha.

\section{Saran}

1. Bagi pelaku usaha harus lebih hati-hati dalam memasarkan produk/jasa, sehingga

${ }^{19}$ Ibid

34 Kemandirian Konsumen.. 
tidak membahayakan keamanan dan keselamatan konsumen

2. Bagi lembaga perlindungan konsumen sebaiknya lebih aktif mensosialisasikan hak-hak konsumen dan membantu memperjuangkan hak-hak konsumen pada saat konsumen dirugikan oleh pelaku usaha

3. Bagi masyarakat, harus ikut aktif memperjuangkan hak-hak konsumen karena pada dasarnya semua orang adalah konsumen yang hak-haknya harus dilindungi

4. Bagi pemerintah, sebaiknya meningkatkan pengawasan terhadap produk/jasa yang beredar serta melakukan pembinaan dan pelatihan terhadap konsumen agar bisa mandiri

$-000-$

\section{DAFTAR PUSTAKA}

Ahmadi Miru, Sutarman, Yodo. 2007. Hukum Perlindungan Konsumen. Jakarta : PT. Raja Grafindo Persada

Gunawan Widjaja, Ahmad Yan. 2003. Hukum Tentang Perlindungan Konsumen. Jakarta : PT. Gramedia Pustaka Utama

Husni Syawali, Neni Sri Imaniyati. 2000. Hukum Perlindungan konsumen. Bandung : Mandar Maju

Janus Sidabalok. 2006. Hukum Perlindungan Konsumen di Indonesia. Bandung : PT. Citra Aditya Bakti

Miru, Ahmadi, dkk. 2004. Hukum Perlindungan Konsumen. Jakarta: PT. Raja Grafindo Persada

Rahayu, Hartini. 2005.Hukum Komersial. Malang:UMM Press.

Sudaryatmo. 1999. Hukum dan Akvokasi Konsumen. Bandung : PT. Citra Aditya Bakti

Shidarta. 2006. Hukum Perlindungan Konsumen Indonesia. Jakarta : PT. Grasindo

Wira Sutedja. 2007. Panduan Layanan Konsumen. Jakarta : PT. Grasindo

Yusuf Shofie. 2003. Perlindungan Konsumen dan
Instrumen-instrumen Hukumnya. Bandung : PT. Citra Aditya Bakti

\section{Peraturan Perundang-undangan :}

Undang-undang No. 8 Tahun 1999 tentang Perlindungan Konsumen

\section{Artikel Internet:}

Direktorat Perlindungan konsumen. Google volume 1.Tanggal akses 17-07-2007

Edi, Suharto. Pendekatan Pekerjaan Sosial Dalam Pemberdayaan Masyarakat Miskin. Google Volume 1. Tanggal Akses 14-072007

Ika Mheutiah. 2004,"Rahasia Dagang dan Perlindungan Konsumen".Google volume 1 tanggal akses 9-04-2007.

Marianus Gaharpung. "Upaya Perlindungan Hukum Bagi Konsumen". Google volume 2 Tanggal akses 9-04-2007

Muhamad Eggi H Suzetta. Pengetahuan hukum untuk konsumen. Google volume 1. tanggal akses 20 Juni 2007

Mu'tadin, Zainun. 2002. Kemandirian Sebagai Kebutuhan Psikologis Remaja. Google volume 1. Tanggal Akses 20-07-2007

Suksmaningsih, Indah. 2003. Perlindungan konsumen Dalam Perspektif Masa Kini. Kompas. Tanggal akses 20-07-2007

Wilkipedia Indonesia. Globalisasi.Google volume 1. tanggal akses 20-07-2007

Wilkipedia Indonesia. Perdagangan Bebas.Google volume 1. Tanggal Akses 17-07-2007

www.Hukumonline.com

www.republika.com

www.konsumen.com

www.pikiran rakyat.com 